\title{
SELECTED ASPECTS OF CREATIVE DRAMA AND SPECIAL NEEDS LEARNERS IN FOREIGN LANGUAGE EDUCATION
}

\author{
S. Hvozdíková, shvozdikova@ukf.sk \\ Constantine the Philosopher University in Nitra, Slovakia
}

\begin{abstract}
The main contribution of the article is the theoretical foundations and research results, which are presented in the context of teaching English as a foreign language to students with attention deficit hyperactivity disorder (ADHD). This article presents a selection of data from a longitude research project that took three years. In particular, it emphasizes the ability of a student with ADHD to respond in a foreign language and the ability to work in that language in a school setting. The article defines the main characteristics of students with ADHD and describes creative drama as an innovative approach to teaching foreign languages. The empirical data of a conducted research are presented. The empirical study was carried out in a secondary public school in the south of Slovakia. The sample for the study was carefully selected, and all data was kept in complete confidentiality. Further research and results are discussed in the following monograph written by the author.
\end{abstract}

Keywords: foreign language education, creative drama, students with ADHD.

\section{Introduction}

The current study deals with the alternative approach to teaching of special needs learners, specifically, the learners diagnosed with the Attention Deficit and Hyperactivity Disorder (ADHD). Considerably, the number of such learners has risen rapidly recent decades. Often teaching of such learners requires special interventions. One of such interventions is introduced in this study. Carefully selected strategies and techniques of creative drama were designed for the purpose of the research presented in this article. Since we appreciate many approaches and methods of teaching foreign languages for the purpose of the research, creative drama techniques were selected for classroom instruction, especially the techniques of still image, slow motion, verbal warm-up, and other paying emphasis on the physical representation of meaning. They served as predictors of foreign language development of the selected learner. Essential contribution of creative drama techniques was examined in the article. Specifically, the study was carried out as a case study of an 11 years old ADHD learner. The results of the case study research showed increase of use of English as a foreign language. Although 11 types of behaviour and level of foreign language cognition were measured, the article discusses one of the observed codes, the Code of English Use in Conversation (named Code seven in the visual representation of the research results).

\section{Theoretical background. Special Needs Learners of Foreign Language}

In the following study we focussed on the special needs learners, specifically, the learners diagnosed with ADHD. They learners represent a group of children often described by teachers and parents as over-energetic and overactive. Scientists characterize Attention Deficit Hyperactivity Disorder children as children with high extent of physical activity, impulsiveness and low self-control behaviour, difficulty to adapt to another activity in the classroom $[3,6,7,14$, $16,18]$. Their behaviour is also characterised as over-aggressive, and inattentive. ADHD learners usually lack expected levels of social competence, their self-esteem is lower than other peers' and level of frustration is very high. Their responses to the smallest impulses are often overexaggerated. The main symptoms are hyperactivity (children are physically over-active), impulsiveness (they respond to actions too quickly), and attention deficit (lack of longer period of attention). Moreover, scientists focus on several main characteristics of ADHD students [7, 8, 16, 18]. They develop the concepts of impulsiveness, attention disorder, hyperactivity, lower social development, and lower self-esteem, memory disorders, perception and cognitive disorders, disorders in conceptualisation and speech.

Historically, it has been recognised that creative drama contributes to the process of the par- 


\section{Интернационализация образования. Образование в странах мира}

ticipants' internalisation of perceptions, and mental representation of reality. Creative drama teachers suggest that creative drama plays an immense role in participants' psychological development $[1,2,4,5,9,12]$. Alongside psychological aspects, drama draws on pedagogical and social foundations. It has been recognized since the early years of the $19^{\text {th }}$ century when pedagogy as a specific and individual subject within the area of social sciences was established, emphasising the essential issues to help children on their journey to the world of knowledge. As recognized early, every child has to be provided with opportunities and called to challenges in order to develop mature critical thinking. Children learn best when they experience learning and when they have the opportunity to develop their knowledge further, when they learn by trials and failures, by searching for the appropriate solutions and by being challenged.

Creative drama makes us explore various imaginary worlds where we may become a part of other personalities, we use language of symbol representing real world [19]. In creative drama we are in imagined role to develop the process and out of role at the same time to evaluate the process. We are aware of the fact that what we do is only as if. He declares that creative drama is a model for exploring the world. Creative drama is learning through experiencing; by active participation, by recognising and participating in spontaneous social situations and social relationships, which transcend the reality of the participant, they learn [12]. Moreover, scientists claim effectiveness of active participation and experiential learning are the key elements of successful foreign language learning [10, 20]. It is impossible to produce language without engagement of the individuals in a dialogue or a group interaction.

Language and drama hold many aspects in common. Social aspect is the essential nature of drama and language they both lay emphasis on context as the key element of drama and language. There is no communication in any language nor there is creative drama happening without social interactions and specific context.

Discussing the issue of traditional approaches to teaching when a learner with his/her whole personality and thinking is not involved in the process of learning fully because the educational experience is not interconnected with his/her real-life context experience [19]. In opposition to traditional teaching, alternative method of teaching English through the tools of creative drama emphasises capturing authenticity and meaning in language.

Narrative aspect of communication has always been a part of life experience. Communication in both, native language or foreign languages often takes place in narrative form. Narration is as close to children as it is to adults or adolescents. Narration has an implication in the process of meaning making [1]. Together with the process of imitation (mimesis) and enactment, they create the core elements of drama in education. Apparently, creative drama may function only in the context of group or team work. Although learners contribute as individuals, a purpose of development of relationships in the classroom is most probably cooperation. Cooperation increases communication and social perception of learners themselves and helps to perceive the others. One of the research study cooperative activities are quite rare in our common classrooms [9]. Too often, children are trained to work individually and to be competitive about their achievements. The meaning of creative drama builds up from the contributions of each individual in the group, and, if the work is to develop, these contributions have to be monitored, understood, accepted and responded to by the rest of the group. Thus, when the contributions of individuals are accepted and we respond to them in a certain way, drama encompasses purpose and meaning. In order to cooperate learners, need to be aware of the importance of their own contributions. Every purposeful and effective drama activity is built on the foundations of individual contributions and active mutual interactions. Generally, active learning provides an opportunity to increase social awareness of language learners and their willingness to take responsibility for their own learning, and respect the ideas and opinions of other learners.

Several research studies have already been conducted about the use of creative drama techniques and their contribution to learning languages, however, there are not many examining the use of creative drama as the intervention techniques [17] in the process of foreign language instruction to ADHD learners. The results of the research showed excellent overall English language production. Moreover, Miccoli's research of college students in the context of second language acquisition in Brazil showed the positive benefits of drama in the oral production of the language [13]. Students were encouraged to take risks in foreign language production, which resulted in better oral performance. The research focussed on development of writing and critical 
thinking development of students when drama strategies were used in the classroom [11]. They both consider language to be multidimensional phenomenon, and thus it is important to study and research the impact of drama on overall language competence as opposed to only segregated skill performance. Many researchers agree that there is a very little classroom research carried out in the field of creative drama in the context of second language acquisition $[13,15]$. In a study, carried out the interactive theatre sessions with the 12 years old students of a secondary school in England (Exeter) to get students involved in the discussion about friendship and future of the humankind in order to maintain justice and well-being [19]. Over the period of several years, he interviewed participants of the Interactive Theatre Programme story, 18 percent had almost full recall of the programme and the story, 48 percent remembered several key aspects of the story and the remainder could remember nothing from the experience. The following part of the article presented the case study research results collected throughout the period of three years. However, one selected variable is only discussed in the article. S. Hvozdíková provides further information in the monograph Teaching Foreign Languages and Special Needs Learners.

Research procedure: Case Study Research

To examine the research questions, the research was divided into two levels. The first was the study of one specific case, the ADHD English language learner. Several research methods were applied in order to examine the case. The major was the qualitative design of one case study of eleven years old boy in the small public school in the south of Slovakia. Within the study of the case, data were collected from the lessons' observations. The main part of the research was the case study of the selected learner. The intervention during the selected lessons included using of creative drama in foreign language teaching at the lower secondary level of education in a small Slovak public school. Furthermore, the research question formulated for the purpose of this study was as follows: Are the selected techniques of creative drama as utilised in the study predictors of the ADHD learner's foreign language enhancement?

\section{Specifications of the sample}

The research sample selection was divided into gradual stages. The main focus of the survey was to find out if there were the children with learning difficulties in our classrooms and what kinds of problems teachers face when teaching foreign languages in the inclusive classrooms.
The secondary aim of the sample selection was to select a school, a teacher and a principal of the school who would be willing to participate in the research and would be willing to change her/his teaching methodology for the time required. The participants and the subjects of the case study had to meet several criteria to be eligible for participation in the research hence a purposeful criterion sampling method was used for recruitment.

The participant had to be officially diagnosed with ADHD. There are many children seemingly hyperactive or behaving socially and academically inappropriate, yet they may not be diagnosed with the ADHD. It may happen that such a child is only having some kind of a developmental period resulting in some specific unaccepted form of behaviour. However, we focused in our recruitment on the children with ADHD diagnosis officially confirmed by special education teacher and psychologist who had been working with the child for at least 6 months' period on regular basis.

The teacher had to have minimum of five years of experience to ensure she is not a novice teacher or initial trainee teacher. This minimum level of experience ensured that the participant had enough knowledge and teaching experience to draw on when practicing the creative drama techniques in teaching English as a foreign language in their classroom. The teacher had to be fully qualified (being a holder of "Mgr." Master's degree in Slovakia) to teach English as a foreign language in a primary or a secondary level of education. The teacher/participant had to have basic knowledge about creative drama in education, specifically in its use in English language teaching.

Apparently, it was crucial to select the appropriate techniques and approaches suitable for the purpose of the case study. Some techniques were refused due to their complex and complicated procedure. Creative drama techniques used in the instruction and the structure of the lessons were the following:

1) Movement warm-ups, verbal warm-ups.

2) Drama technique of still image.

3) Drama technique of non-verbal communication, miming.

4) Drama technique of role-plays and verbal communication.

5) Paper/fabric ball throwing and catching.

6) Drawing.

7) Drama technique of slow-motion.

The lessons were structured as follows:

A) Warm-up, B) introduction, C) development 


\section{Интернационализация образования. Образование в странах мира}

of the topic (usually drama included based on the text or verbal instruction), D) follow -ups, E) calm-downs. Classroom management was held in a non-traditional setting, all the lessons were arranged in a circle either sitting on the chairs or on the floor, without common rows. The desks were kept aside and children moved freely in the classroom. However, the circles and the group management was kept organised. The teacher was the facilitator or a role-play partner. Further lesson plans or other information regarding the techniques and structure/management of the classes are available on request.

\section{Case study research results}

Several selected codes of observation were selected as viewed in the chart (Table 1). Analysis of the Code seven was selected for the purpose of this study. The other six Codes of observation were discussed in the author's monograph Teaching Foreign Languages and Special Needs Learners (2020).

\begin{tabular}{|l|l|}
\multicolumn{2}{c}{ The Observed Codes } \\
\hline Code one & $\begin{array}{l}\text { Use of language unit in a correct } \\
\text { context }\end{array}$ \\
\hline Code two & $\begin{array}{l}\text { Following teacher's instructions } \\
\text { in English }\end{array}$ \\
\hline Code three & Using the studied unit correctly \\
\hline Code four & $\begin{array}{l}\text { Answers correctly based } \\
\text { on comprehension }\end{array}$ \\
\hline Code five & Using other language units correctly \\
\hline Code six & Improvising in using English \\
\hline Code seven & Using English in conversation \\
\hline
\end{tabular}

The following data present the occurrence of the selected phenomena during the most intense phase of the intervention: April. In order to compare with the data collected before the intervention began the records were examined. To create exact records of the number of occurrences after the intervention began was fundamental in order to compare them with the baseline of the records before it had begun. The following trend-line shows the occurrence of use of English during the most intense phase of the intervention when the techniques of creative drama were gradual included into the process of teaching English to the class that Jim attended. As the trend-line shows (Fig. 1) his use of English raised. He utilised mostly simple words and phrases the teacher introduced during the lesson as derived from the content of the individual lesson. He was not able to produce his own spontaneous language. At the age of 11 he was still a beginner learner.

The trend-line clearly shows the tendency towards English language improvement in terms of using the language in conversation. The learner used those parts of language vocabulary and the language structures that had been introduced during the observed lesson.

\section{Summary of the research results}

Apparently, the findings presented the creative drama techniques as utilised in the context of the research as a very effective tool in foreign language instruction with the specific attention paid to the learners with ADHD. The findings showed a very positive response of the learner with the deficit to the modified lessons, as did his peers. Generally, as observed, creative drama supported friendly atmosphere, created positive social dynamics, which both increased learner's motivation and self-confidence in foreign language use. Moreover, the results of observations and from the individual interviews, Jim showed lower number of ADHD symptoms, mainly, the symptom of attention and concentration deficits as well as disturbing behaviour compared with the number of behavioural problems

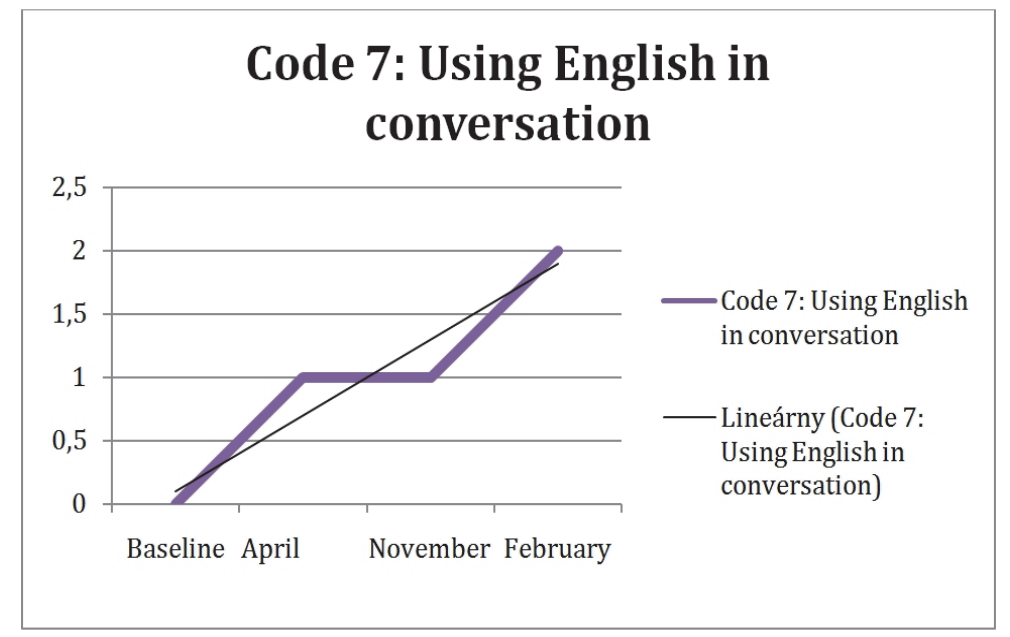

Fig. 1. Trend-line of the selected code: Using English in conversation 
before the modification of the lessons began. Based on the individual interviews the results showed increased Jim's self-motivation and selfconfidence. Increased verbal and non-verbal communication during the course of the intervention contributed to increase Jim's attention span. The English teacher expressed her satisfaction with Jim's behaviour, Jim showed more interest in the lesson and he paid more attention to the content of the lessons. He enjoyed variety of the activities and tasks he had been assigned.

As the trend-lines indicated, the tendency of negative elements of his behaviour during the course of intervention was descending. However, sometime after the intervention when the occurrences were recorded, he was very nervous from the camera recording the class. Furthermore, Jim did not show much of correct English language production. More often, he showed excitement and surprise. Considering the trendline Using English in Conversation, it indicates increased trends. As the teacher responded in one of the interviews, Jim had not used English in conversation at all. Clearly, there was an expected increased number of observed English words and phrases used in his conversation.

\section{Summary}

The purpose of the study was to present the results of the case study research that the research team conducted in a public school in Slovakia. The subject of the research was carefully selected. It was an eleven years old boy diagnosed with ADHD, learning English as a foreign language, his level of proficiency was beginner. The research was based on the presumption that the specifically selected creative drama techniques utilised in language teaching might have contributed to the progress displayed in the study. The results of the case study supported the presumption of improving foreign language skills of the ADHD learners when the intervention creative drama techniques were used in teaching English as a foreign language. The future research is planned to aim at higher number of the learners' research subjects and to the longitudinal approach to the research.

Publication of the article was supported by the APVV (Slovak Research and Development Agency) under the contract number APVV-17-0071 and the VEGA (National Grant Research Agency) under the contract number VEGA 1/0062/19.

\section{References}

1. Bolton G. New Perspectives on Classroom Drama. London, Simon and Schuster Education, 1992. $147 \mathrm{p}$.
2. Farmer D. Drama strategies. London, 2011. Available at: http://www.dramaresource. $\mathrm{com} / \mathrm{strategies}$ (accessed 21.06.2017).

3. Fabiano G.A., Pelham W.E. Improving the Effectiveness of Behavioural Classroom Interventions for Attention-Deficit/Hyperactivity Disorder: A Case Study. Journal of Emotional and Behavioral Disorders, Hammill Institute on Disabilities and SAGE Publication, 2003, vol. 11, no. 2 , pp. $122-128$. DOI: $10.1177 / 10634266030$ 1100206

4. Heathcote D. Collected Writings on Education and Drama. London, Hutchinson Group Ltd., 1984. 220 p.

5. Hillyard S. Teaching English through Educational Drama to Students with Learning Difficulties. London, 2010. Available at: http:// learning2gether.pbworks.com/w/file/fetch/5216 5078/TheoreticalBackground EiA BIB SH.pdf (accessed 12.02.2015).

6. Homolová E. Teaching of English Learners with Disabilities and Special Educational Needs. Teaching Learners with Disorders. Univerzita Hradec Králové, Gaudeamus, 2012, 128 p. DOI: 10.17846/SEN.2015.7-28

7. Jucovičová D., Záčková H. Hyperactive and Non-attentive Child at Home and at School. Praha, Grada, 2010. 238 p.

8. Kaldonek-Crnjakovic A. The Cognitive Effects of ADHD on Leaning an Additional Language. Warsaw, Govor, 2018, vol. 35, pp. 201-207.

9. Lambert A., O’Neill C. Drama Structures. London, Hutchinson Education, 1982. 240 p.

10. Larsen-Freeman D. Techniques and Principles in Language Teaching. Oxford, Oxford University Press, 2000. $191 \mathrm{p}$.

11. Liu M. Predicting Effects of Personality Traits, Self-Esteem, Language Class Risk-Taking and Sociability on Chinese University EFL Learners' Performance in English. Journal of Second Language Teaching and Research 1, 2012, vol. 1, p. 30. DOI: 10.5420 /jsltr.01.01.3318

12. Machková E. Introduction to the Study of Drama Education. Praha, IPOS - Informační a poradenské středisko pro místní kulturu, 1998. 199 p.

13. Miccoli L. English Through Drama for Oral Skills Development. UK: ELT Journal, 2003, vol. 57, iss. 2, pp. 122-129. DOI: 10.1093/elt/57.2.122

14. Munden A., Arcelus J. Attention Deficit and Hyperactivity Disorder. Praha, Portal, 2006. $120 \mathrm{p}$.

15. Ntelioglou B. "Why do I Have to Take This Class?" The Mandatory Drama-ESL Class and Multiliteracies Pedagogy. Research in Drama 


\title{
Интернационализация образования. Образование в странах мира
}

Education: The Journal of Applied Theatre and Performance, London, 2011, pp. 596-615. DOI: 10.1080/13569783.2011.617108

16. Rief S. How to Reach and Teach Children with ADHD/ADD. Practical Techniques, Strategies, and Interventions. New York, John Wiley \& Sons Inc, 2005. $464 \mathrm{p}$.

17. Riley-Tillman T.CH., Burns M.K. Evaluating Educational Interventions. Single-Case Design for Measuring Response to Intervention. New York, The Guilford Press, 2009. 214 p. DOI: $10.1080 / 07317107.2012 .707102$
18. Serfontein G. The Hidden Handicap. How to Help Children Who Suffer from Dyslexia, Hyperactivity and Learning Difficulties. London, Simon and Schuster Ltd, 1990. 176 p.

19. Somers J. Story, Intertextuality and Drama in Education. The Journal for Drama in Education, London, National Association for the Teaching of Drama NATD, 2008, vol. 18, iss. 1, pp. 64-71.

20. Stranovská E. Psycholinguistics: Selected Determinants of Learning a Foreign Language and Its Culture. Brno, MSD, 2011, p. 316.

Received 18 January 2021

\section{ИЗБРАННЫЕ АСПЕКТЫ ТВОРЧЕСКОЙ ДРАМЫ И ОСОБЫЕ ПОТРЕБНОСТИ ИЗУЧЕНИЯ В ОБРАЗОВАНИИ ИНОСТРАННОГО ЯЗЫКА}

\section{С. Хвоздикова}

\author{
Университет им. Константина Философра в Нитре, г. Нитра, Словакия
}

\begin{abstract}
Основным вкладом статьи являются теоретические основы и результаты исследований, которые представлены в контексте обучения английскому языку как иностранному учащихся с синдромом дефицита внимания и гиперактивностью (СДВГ). В статье представлены данные лонгитюдного исследования, которое продолжалось три года. В результатах исследования подчеркивается способность учащегося с СДВГ отвечать на иностранном языке и способность работать на этом языке в школьной обстановке. В статье определяются основные характеристики учащихся с СДВГ и описывается творческая драма в качестве инновационного подхода к обучению иностранным языкам; представлены эмпирические данные проведенного исследования. Эмпирическое исследование было проведено в средней государственной школе на юге Словакии. Выборка для исследования была тщательно отобрана, и все данные хранились в полной конфиденциальности. Дальнейшие исследования и результаты обсуждаются в следующей монографии, написанной автором.

Ключевые слова: иноязычное образование, творческая драма, учашиеся с СДВГ.
\end{abstract}

Хвоздикова Сильвия, магистр, кандидат наук, доктор, доктор философии, Кафедра английского языка и американистики, факультет искусств, Университет Константина Философа в Нитре, г. Нитра, Словакия, shvozdikova@ukf.sk.

Поступила в редакцию 18 января 20212.

\section{ОБРАЗЕЦ ЦИТИРОВАНИЯ}

Hvozdíková, S. Selected Aspects of Creative Drama and Special Needs Learners in Foreign Language Education / S. Hvozdíková // Вестник ЮУрГУ. Серия «Образование. Педагогические науки». - 2021. - Т. 13, № 2. C. $107-112$. DOI: $10.14529 /$ ped210210

\section{FOR CITATION}

Hvozdíková S. Selected Aspects of Creative Drama and Special Needs Learners in Foreign Language Education. Bulletin of the South Ural State University. Ser. Education. Educational Sciences. 2021, vol. 13, no. 2, pp. 107-112. DOI: 10.14529/ped210210 